\title{
Balkans briefing number 5. Seeking refuge (Macedonia, 9-25 June 1999): the changing needs of humanitarian aid in the face of the peace
}

John Ashton

NHS Executive North

West, 930-932

Birchwood Boulevard,

Millennium Park,

Birchwood,

Warrington WA3 7QN

Correspondence to:

Professor Ashton, CBE

(e-mail:

jech@liverpool.ac.uk)

Accepted for publication

17 February 2000

\begin{tabular}{|c|c|c|c|c|c|}
\hline Country & $\begin{array}{l}\text { Departures } \\
\text { 20 Jun } 99\end{array}$ & $\begin{array}{c}\text { Total } \\
\text { departures } \\
\text { to date }\end{array}$ & $\begin{array}{c}\text { Scheduled } \\
\text { departures } \\
21 \text { Jun } 99\end{array}$ & $\begin{array}{l}\text { Scheduled } \\
\text { departures } \\
21-27 \text { Jun }\end{array}$ & Quotas \\
\hline Andorra & & & & & $6-10$ cases \\
\hline Argentina & & & & & 500 \\
\hline Australia & & 3,470 & & & 4,000 \\
\hline Austria & & 5,079 & & & 5,000 \\
\hline Belgium & & 1,223 & & & 1,200 \\
\hline Brazil & & & & & 100 \\
\hline Canada & 46 & 5,317 & & & 5,000 \\
\hline Chile & & & & & 500 \\
\hline Croatia & & 370 & & & 5,000 \\
\hline $\begin{array}{l}\text { Czech } \\
\text { Republic }\end{array}$ & & 824 & & & 100 's \\
\hline Denmark & & 2,823 & & & 3,000 \\
\hline Estoria & & & & & 15 \\
\hline Finland & & 958 & & & 1,000 \\
\hline France & & 5,796 & 204 & 612 & not available \\
\hline Germany & & 14,689 & & & 15,000 \\
\hline Greece & & & & & 5,000 \\
\hline Iceland & & 70 & & & 100 \\
\hline Ireland & & 1,033 & & & 1,000 \\
\hline Israel & & 206 & & & not available \\
\hline Italy & & 6,199 & & & 10,000 \\
\hline Lithuania & & & & & 100 \\
\hline Luxemburg & & 101 & & & not available \\
\hline Malta & & 105 & & & 100 \\
\hline Moldova & & & & & 75 \\
\hline Netherlands & & 4,067 & & & 4,000 \\
\hline New Zealand & & & & & 1,000 \\
\hline Norway & & 6,075 & & & 6,000 \\
\hline Poland & & 1,049 & & & 1,000 \\
\hline Portugal & & 1,271 & & & 2,000 \\
\hline Romania & & 41 & & & 5,000 \\
\hline Slovakia & & 90 & & & 500 \\
\hline Slovenia & & 860 & & & 1,600 \\
\hline Spain & & 1,426 & & & 1,800 \\
\hline Sweden & & 3,675 & & 163 & 5,000 \\
\hline Switzerland & & 1,687 & & & 2,500 \\
\hline Turkey & & 8,105 & & 736 & 20,000 \\
\hline $\begin{array}{l}\text { United } \\
\text { Kingdom }\end{array}$ & & 4,191 & & 157 & 1000 's \\
\hline USA & & 7,126 & & 832 & 20,000 \\
\hline Uruguai & & & & & not available \\
\hline TOTAL & 46 & 87,926 & 204 & 2,500 & \\
\hline
\end{tabular}

Figure 1 UNHCR/IOM Humanitarian Evacuation Programme (HEP) 21 fune 1999. kane prioritet.

- Familjet, qe qendrojne "kohe te gjate" ketu do te kene prioritet per evakuim.

- Ne femi ketu per te ndihmuar." (British Team Skopje 1999-Humanitarian Evacuation:

- "We will evacuate refugees from Kosovo.

- No one will be forced to leave against their will.
- Family unity must be preserved. Families will not be separated for humanitarian evacuation.

- Refugees in the most difficult situation because of family situation or health problems will go first.

- Vulnerable families with small children, single parents, elderly persons or family members with serious medical problems are a priority.

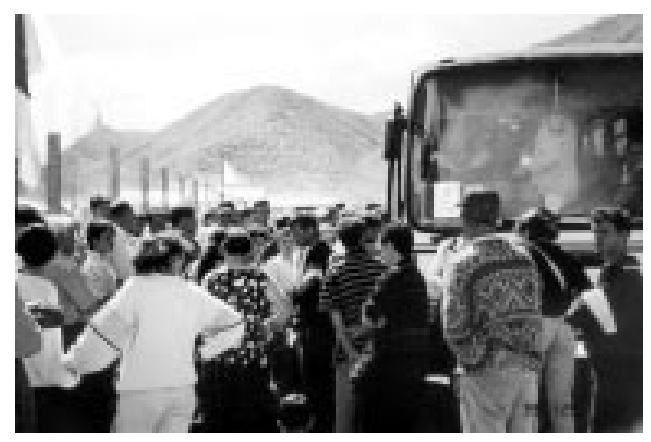

Figure 2 Last sight of Macedonia for Kosovar refugees being evacutated from Skopje airport.

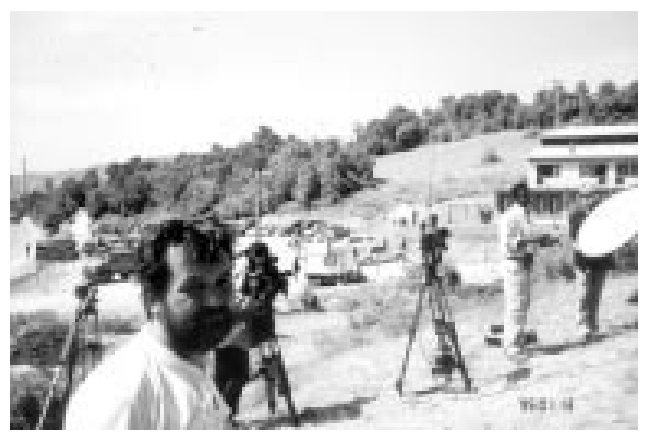

Figure 3 The world's media descend on the peace talks at the Kosovo-Macedonia border.

\begin{tabular}{|lr|}
\hline Stenkovec 1 (Brazda) & 21,400 \\
Stenkovec 11 & 20,600 \\
Bojane & 3,800 \\
Neprosteno & 8,300 \\
Radusa & 2,500 \\
Senokos & 6,800 \\
Cegrane & 41,000 \\
Total & $\mathbf{1 0 4 , 0 0 0}$ \\
\hline
\end{tabular}

Figure 4 Refugees in camps in Macedonia (former republic of Yugoslavia) in early fune 1999. 


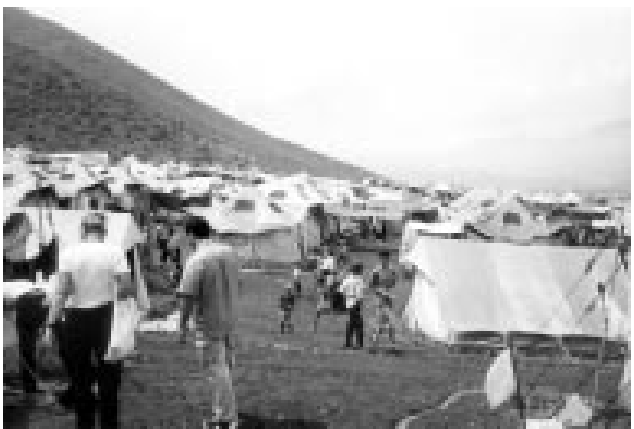

Figure 5 Refugees in camp in Macedonia.

- Consideration will also be given to long-stay cases.

- We are here to help you.")

Such was the British delegation interpretation of the United Nations High Commission on Refugees mission statement for Kosovo on the ground. Beginning in early April 1999 the largest displacement of civilians in Europe since the second world war had led to hundreds of thousands of Kosovans being relocated to refugee camps and supportive families in the community particularly in Albania and Macedonia. The countries of the European Union, the United States of America and other members of the UN family became actively engaged in the humanitarian relief effort. By the beginning of June tens of thousands of men, women and children had been evacuated and transported around the globe (figs 1 and 2).

The public health aspects of this mobilisation have been described from a British perspective in previous articles in this series. ${ }^{1-4}$ By the time the emergency was over, more than 4000 people would have travelled to the United Kingdom, the overwhelming majority to the two northern regions, in and around Liverpool, Manchester and Leeds-Bradford. Initially, the refugees were in large family groups, sometimes of 10 or 15 people, with a range of ages, both sexes and with a smallish number experiencing serious health problems. Their main problems were psychological, to do with their recent, often extremely stressful, experiences

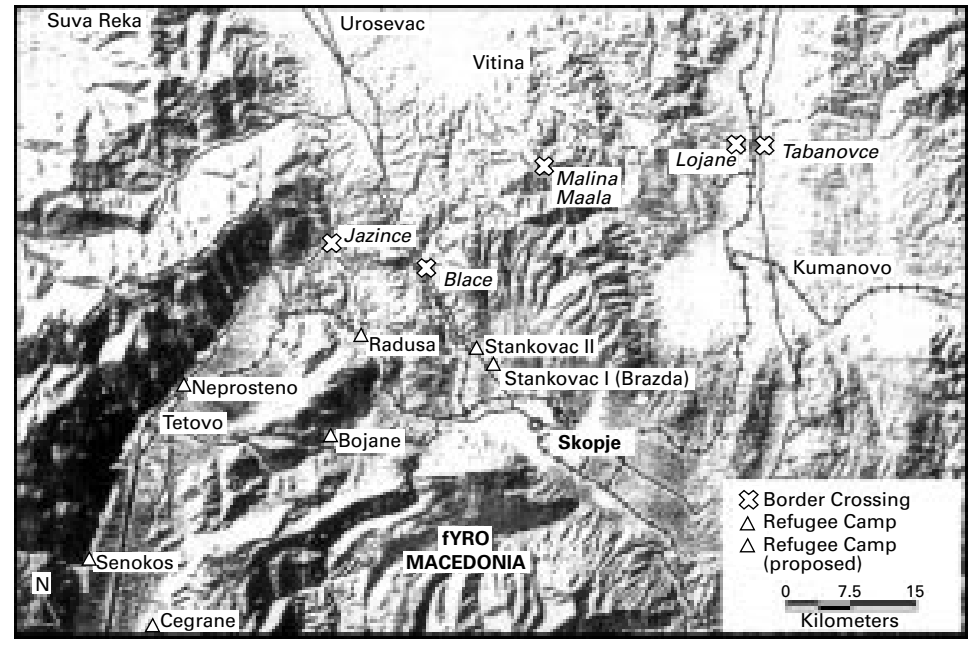

Figure 6 Refugee centres and sites in northern Macedonia (former republic of Yugoslavia) fune 1999. and physical and emotional exhaustion. They were met by a remarkable local response of overwhelming hospitality in the main, and the inter-agency arrangements of social work, health, housing and social security worked extremely well. Because of the large numbers coming to the north an early decision was made to have a local public health presence from the north-west region on the ground at the Macedonian end. ${ }^{2}$ In early June, at the time of the handover of personnel, the situation in the Balkans changed dramatically with the signing of the peace agreement with concomitant implications for the direction of the humanitarian effort (fig 3 ).

\section{A change of emphasis from families to those at medical risk}

On 27 May the United Nations War Crimes Tribunal indicted Slobodan Milosevic for crimes against humanity. Five days later peace negotiators considered a letter from Milosevic that was said to accept the basic principles of a deal. On 10 June the peace agreement was signed.

At this time over 100000 refugees were living in seven camps in the area of Macedonia just inside the border from Kosovo (figs 4, 5, 6).

Once the peace had been agreed, almost immediately national delegations began to develop plans to withdraw and to close down their operations (figs 7 and 8).

The problem with this development related to the situation in which many people and families in the camps, and in the wider community, with serious health problems still found themselves. Reports were coming in of the degraded state of the health care system in Kosovo itself and, despite the best efforts of the international non-governmental agencies that were providing clinical care in the camps, they could not begin to provide the kind of specialist interventions that many people needed as a

\begin{tabular}{|lll|}
\hline Country & End Date & Remarks \\
Australia & $20 / 06 / 99$ & \\
Austria & $08 / 06 / 99$ & \\
Belgium & $04 / 05 / 99$ & $\begin{array}{l}\text { Quota full. Only accepting family } \\
\text { Canada }\end{array}$ \\
Croatia & 17.06 .99 & reunions \\
Czech Rep & 18.05 .99$. & \\
Dermark & 15.06 .99$. & Still considering medical cases. \\
Finland & & (Approximately.) \\
France & $07 / 07 / 99$ & \\
Germany & $16 / 06 / 99$ & \\
Iceland & $19 / 05 / 99$ & \\
Ireland & $17 / 06 / 99$ & \\
Israel & $26 / 05 / 99$ & Taking medical cases. \\
Italy & $15 / 06 / 99$ & \\
Luxembourg & $26 / 05 / 99$ & \\
Malta & $31 / 05 / 99$ & Taking family reunions. \\
Netherlands & & \\
New Zealand & $31 / 05 / 99$ & \\
Norway & $05 / 05 / 99$ & Last flights being organised. \\
Poland & & No longer selecting. \\
Portugal & & No longer selecting. \\
Romania & & No longer selecting. \\
Slovakia & & Still selecting 400 persons. \\
Slovenia & & Considering medical cases. \\
Spain & Considering medical cases. \\
Sweden & & Considering medical case. \\
Switzerland & & Rut still taking medical cases. \\
Turkey & & \\
UK & & \\
USA & $25 / 06 / 99$ & \\
\hline
\end{tabular}

Figure 7 Health Evacuation Programme Countries with programme end date (situation analysis 21 fune 1999). 


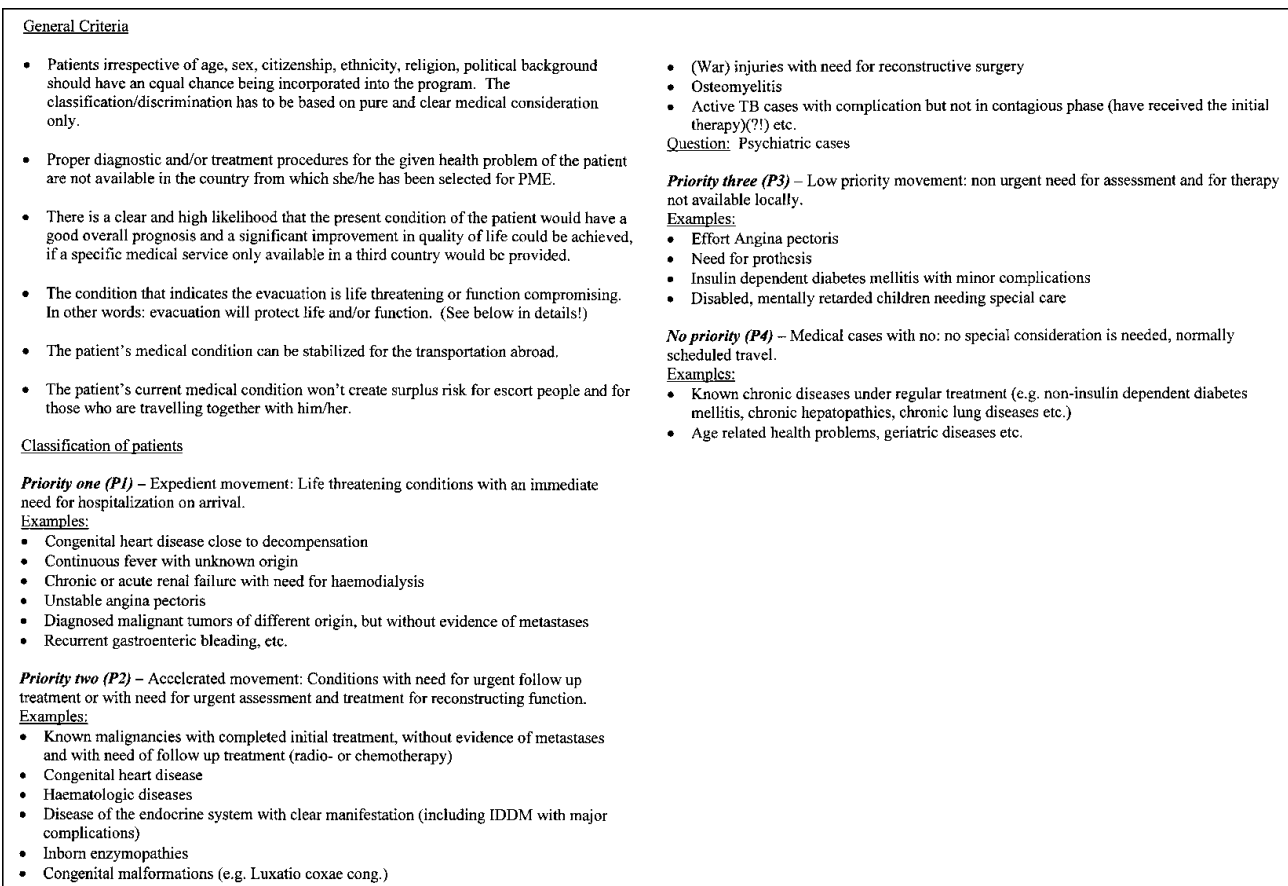

Figure 8 General criteria and classification of patients selected for Priority Medical Evacuation (PME).

matter of some urgency. On the ground outside the camps, Macedonian hospitals and primary care centres were struggling under the huge

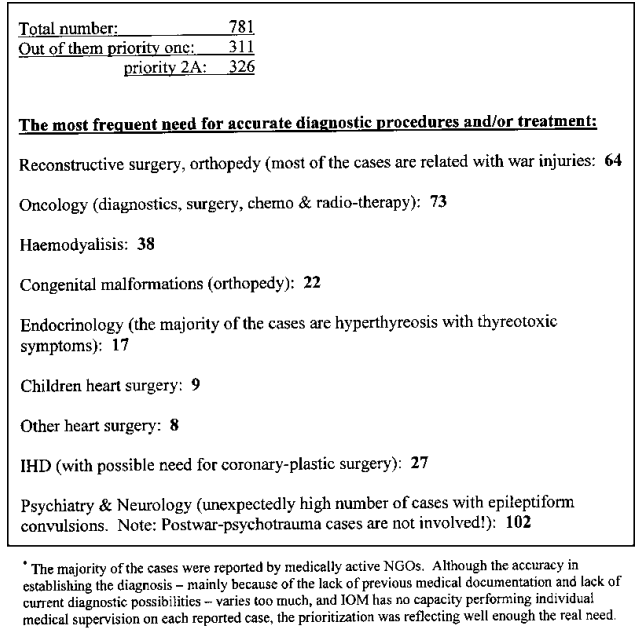

Figure 9 Review of priority medical cases * until now and still not evacuated.

- 39 year old woman with acute thyrotoxicosis.

- Young adult man needing mandibular reconstruction following bullet wounds

- Older man with complex fracture of tibular and fibular and retained bullet.

- 44 year old man with gunshot wounds

- 5 year old child with vesico-uteric reflux

- 55 year old man with renal calculi

- 66year old woman with a large ovarian tumour

- Young woman with diagnosed but untreated ovarian cancer

- 36 year old woman with newly diagnosed breast cancer

- 12 year old girl with acute lymphoblastic leukaemia

- 54 year old man with testicular tumour

- 1 year old boy with an untreated cleft lip and palate ( one of many)

- 1 year old girl with untreated spina bifida

- 6 year old boy with cystic fibrosis

- 6 year old boy with cystic fibrosis

- 57 year old man with post traumatic stress following brutal treatment by para-militaries

- 3 year old girl with unstable epilepsy

- 20 year old woman with pregnancy complications

Figure 10 Priority medical cases for evacuation from Macedonia, Fune 1999. additional burden imposed by the swollen refugee population. Underlying the dilemma, despite the best efforts of the World Health Organisation in setting up a disease surveillance system, ${ }^{3}$ was the dearth of information about the extent of the problem. At the daily meetings of the local UNHCR office attention switched to two things:

- how to get some decent intelligence on health needs in the camps and beyond, and

- how to maintain the engagement of country delegations in evacuating people in medical need for a while longer.

People with serious health problems had no prospect of having their needs met in the camps or locally in Macedonia, and if they were to return home there was scant prospect of their needs being met even in the teaching hospital in Pristina for the foreseeable future.

Under this pressure and working together with the country delegations and nongovernmental organisations, the United Nations agency IOM (International Organisation Migration), and the sole public health doctor from the UK, a clear set of criteria for classifying patients for Priority Medical Evacuation was agreed, and during a hectic weekend casenotes and other recorded information were sifted and appraised using the classification, producing at the end of the exercise a single page summary with additional analysis by camp, location and severity as the basis for further mobilisation and evacuation (figs 9 and 10).

Armed with this information it began to be possible for individual delegate members to make representations at home and through the international bodies to develop a coherent and effective approach to this new phase of the emergency. The components of this were identified as being: 


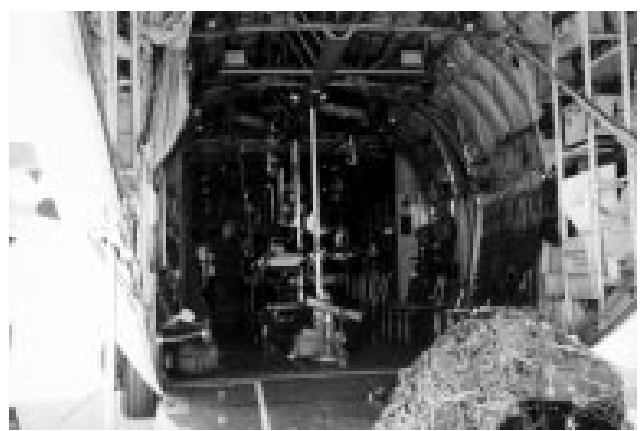

Figure 11 Royal Air Force Hercules ambulance plane evacuating priority one medical refugees to the United Kingdom.

- Maintaining adequate primary health care within the Macedonian camps until all the refugees are able to return home.

- Maintaining medical supplies (in particular for example insulin, antiepileptic drugs and painkillers) with robust systems to ensure that supplies reach the clinical staff who need them.

- To provide more specialist staff and services including additional support to local hospitals and continuing medical evacuation if needed.

- To ensure effective collaboration between agencies and national delegations in the process of rebuilding capacity in the Kosovan health and healthcare systems.

In the event, the willingness of some countries to continue with their medical evacuations, coupled with appropriate representations to other countries based on the epidemiological analysis of priority medical need, enabled the necessary continuing mobilisation to occur. A typical manifest of evacuees is shown in figure 10
Three hundred and eleven Priority 1 medical cases may seem a lot to any one health care system, but a problem shared is a problem halved and when many countries agree to play their part it can become readily manageable.

\section{Footnote-living in real time}

Public health practice in a humanitarian aid situation is different from the kind of business and planning cycles that characterise large public sector organisations. It is necessary for people to think on their feet and to mobilise resources in timescales of hours and days rather than the customary weeks and years. Yet organisation, planning and continuity are also required. It is a personal view based on my Balkan experience that this kind of work requires public health expertise, systematically applied but in a light footed way. I think though that there is a corollary that entails more living in real time, more hands on in the day to day practice of public health in the UK and elsewhere. I suspect that our predecessors knew this but that it has been lost somewhere as we have developed elaborate bureaucracies, and business planning has become a kind of fetish.

1. Duff $\mathrm{CH}$. Balkan briefing. Reflections on the health of a refugee population. $f$ Epidemiol Community Health 1999;53:578-9.

2 Gent RN. Balkan briefing. Abuses of human rights in the Kosovo region of the Balkans. If Epidemiol Community Health 1999;53:594-6.

3 Brusin S. The communicable disease surveillance system in the Kosovar refugee camps in the former Yugoslav Republic of Macedonia, April-August 1999. F Epidemiol Community Health 2000; 54:52-7.

4 Sram I, Ward D. Kosovo refugees in the North West Region of the United Kingdom. I Epidemiol Community Health 2000:54:314-17. 